\title{
SIZE AND SEX COMPOSITION OF TWO SPECIES OF THE GENUS ATLANTORAJA (ELASMOBRANCHII, RAJIDAE) CAUGHT BY THE BOTTOM TRAWL FISHERIES OPERATING ON THE URUGUAYAN CONTINENTAL SHELF (SOUTHWESTERN ATLANTIC OCEAN)
}

\author{
${\text { Luis } \text { Orlando }^{1 *} \text {, Ines Pereyra }}^{l}$, Laura Paesch ${ }^{l}$ and Walter Norbis ${ }^{1,2}$ \\ ${ }^{1}$ Dirección Nacional de Recursos Acuáticos (DINARA) \\ Departamento de Biología Pesquera \\ (Constituyente 1497, C. P.: 11200 - P.O. Box 1612, Montevideo, Uruguay) \\ ${ }^{2}$ Facultad de Ciencias, Departamento de Biología Animal, \\ Laboratorio de Fisiología de la Reproducción y Ecología de Peces \\ (Iguá 4225, Montevideo, Uruguay) \\ *Correspondig author: lorlandoch@gmail.com
}

\begin{abstract}
A B S TR A C T
In this work we analyzed the spatial and seasonal variation of length distribution, sexual proportion and mature dominance for Atlantoraja cyclophora and A. castelnaui, at the Uruguayan continental shelf. There were significant differences in total length (TL) composition between sexes, being females bigger than males for both species. Atlantoraja cyclophora showed a relatively uniform length distribution between inner and outer shelf. There were no major variations in the sex compositions and in the mature dominance between seasons, suggesting no temporal variation. Atlantoraja castelnaui showed a significant variation in its spatial and seasonal distribution. Individuals were smaller in inner shelf, pointing out the existence of juvenile zone in areas up to $50 \mathrm{~m}$ depth. A tendency to capture smaller individuals towards the end of the year was observed. In all seasons over $50 \%$ of females were caught below the estimated size at maturity, suggesting that this species is highly susceptible to exploitation.
\end{abstract}

\section{R E S UMO}

Neste trabalho foi analisada a variação espacial e temporal da distribuição de comprimento, proporções sexuais e dominância de maduros para Atlantoraja cyclophora e A. castelanui, na plataforma continental uruguaia. Houve diferenças significativas na distribução do comprimento total (TL) entre os sexos, sendo as fêmeas maiores que os machos para ambas espécies. Atlantoraja cyclophora mostrou uma distribuição relativamente uniforme de comprimento entre a prataforma interna e externa. Não houviram grandes variações nas composições do sexo e na dominância de maduros entre as estações do ano, sugerindo que não ha variação temporal. Atlantoraja castelnaui mostrou uma variação significativa na sua distribuição espacial e sazonal. Os indivíduos foram menores na plataforma interna, apontando para a existência de uma zona de juvenis em áreas de até $50 \mathrm{~m}$ de profundidade. A tendência para a captura de indivíduos menores no final do ano foi observada. Em todas as estações do ano mais de 50\% das fêmeas foram capturadas em um comprimento menor ao tamanho estimado de maturidade observado na literatura, sugerindo que esta espécie é altamente suscetível à explotação.

Descriptors: Skates, Exploitation vulnerability, Population, Spatial-temporal patterns.

Descritores: Rayas, Vulnerabilidade a explotação, População, Padrões espaço-temporal.

\section{INTRODUCTION}

Skates (Rajidae) are thought to be particularly vulnerable to fisheries because many of them are of large body size, and present slow growth rate, late maturity and low fecundity (HOLDEN, 1973; DULVY et al., 2000; DULVY; REYNOLDS, 2002). In addition to this, they are vulnerable to trawl fisheries because of their demersal life-style on soft bottom substrates (EBERT; SULIKOWSKI, 2007). Fisheries may alter size structure and population parameters in response to changes in species abundance (STEVENS et al., 2000). In the statistics of many fisheries, skate capture data are usually recorded in only one category, this has masked cases of shifts in community composition and local extinctions (DULVY et al., 2000; STEVENS et al., 2000). 
The skate genus Atlantoraja consists of three species; Atlantoraja castelnaui (Ribeiro, 1907), Atlantoraja cyclophora (Regan, 1903) and Atlantoraja platana (Gunther, 1880). All of them are considered endemic to the southwestern Atlantic. On the Uruguayan continental shelf A. cyclophora and A. castelnaui populations are by-catch mainly of the commercial bottom trawl fisheries for whitemouth croaker (Micropogonias furnieri) (ODDONE et al., 2005; PAESCH; DOMINGO, 2003). Detailed landing statistics are not available by species, and catches are often considerably underestimated (ODDONE et al., 2005; PAESCH; DOMINGO, 2003). This scenario of intensive fisheries and low quality information has already led to the overexploitation of several species of demersal elasmobranchs in the southwestern Atlantic (VOOREN; KLIPPEL, 2005).

Atlantoraja cyclophora is distributed along the coast from Cabo Frio, Brazil $\left(22^{\circ} \mathrm{S}\right)$ to Golfo de San Jorge in Argentina $\left(47^{\circ} \mathrm{S}\right)$ (COUSSEAU; PERROTTA, 2004), is found from the coast out to depths of $300 \mathrm{~m}$ (ODDONE; VOOREN, 2004). In Uruguayan waters this species is commonly distributed along the 200-meter isobath (COUSSEAU; PERROTTA, 2004). In southern Brazilian waters the size at $50 \%$ of sexual maturity was estimated at 52.8 $\mathrm{cm}$ of total length (TL) for females and $48.5 \mathrm{~cm}$ for males, and oviposition has been registered at similar intensities during summer/autumn and winter (ODDONE; VOOREN, 2005). Atlantoraja castelnaui is the largest and one of the most common rajids in the southern Brazilian and Bonaerensean districts (MENNI, 1973). It is distributed from Rio de Janeiro, Brazil to $40^{\circ} \mathrm{S}$ in Argentinian waters (COUSSEAU; PERROTTA, 2004), occurring at depths from 20 to $220 \mathrm{~m}$ (VOOREN, 1997). Its size at $50 \%$ of sexual maturity has been reported at $112 \mathrm{~cm}$ of $\mathrm{TL}$ for females and $93 \mathrm{~cm}$ for males (ODDONE et al., 2005). Studies carried out in southern Brazilian coastal waters showed an egg laying peak in January (PERES; VOOREN, 1993; ODDONE et al., 2008).

Despite the fact that the Uruguayan continental shelf accounts for an important portion of these species' distribution, there is no information on population structure and spatial patterns for this area. In view of this lack of information and the concern for the vulnerability of these species, the aim of this study was to analyze spatial-temporal variations in size, sex, and sexual stage in the catch composition of $A$. castelnaui and A. cyclophora obtained from commercial bottom trawling vessels.

\section{Material and Methods}

$$
\text { Study Area and Sampling }
$$

Data were obtained through the On Board Observers Program of the Uruguayan National Office of Aquatic Resources (DINARA), during the year 2004, on 4 bottom trawl commercial fishery vessels that operated from the harbor of La Paloma (Rocha, Uruguay). These ships were $32.78 \mathrm{~m}$ long and of 218 GRT (gross registered tons) and $330 \mathrm{HP}$ (horse power). Fishing was performed with pelagic nets adapted for bottom trawling with 40, 60 and $100 \mathrm{~mm}$ (stretched mesh) codend and otter boards. The horizontal and vertical opening of the fishing nets was approximately $25 \mathrm{~m}$ and $3 \mathrm{~m}$, respectively. The study area was situated between $34^{\circ} 10^{\prime} \mathrm{S}$ and $36^{\circ} 05^{\prime} \mathrm{S}$ at depths from 20 down to $140 \mathrm{~m}$ (Fig. 1).

Position at each fishing station was recorded at the beginning of a 90 minute tow, conducted at a towing speed of approximately 3 knots during daylight. Sex, TL rounded down to the nearest $\mathrm{cm}$ and disc width (DW) (sensu MCEACHRAN; CARVALHO, 2002) for A. castelnaui and $A$. cyclophora were recorded. Data were assembled and analyzed by season: summer (January to March), autumn (April to June), winter (July to September) and spring (October to December). TL at 50\% maturity $\left(\mathrm{TLM}_{50}\right)$ estimated by Oddone et al. (2008a), for $A$. castelnaui, and Oddone and Vooren (2005), for $A$. cyclophora, were used as criteria to separate immature and mature individuals.

\section{Data Analysis}

Parametric or non-parametric tests were chosen after normality and homogeneity of variance had been tested by Shapiro-Wilk and Levene's tests, respectively (ZAR, 2004). In order to test differences in the TL compositions caught by different mesh sizes (40, 60 and $100 \mathrm{~mm})$ a Kruskal-Wallis (KW) nonparametric analysis of variance and a Mann-Whitney (MW) a posteriori test with Bonferroni's correction were applied (SOKAL; ROHLF, 1998). For detecting differences in the TL distributions by sex a Kolmogorov-Smirnov test (KS) was performed. Sex ratio and predominance of mature or immature individuals were tested within seasons using the chisquared test $\left(\chi^{2}\right)$ for both species. To compare the TL data by season a KW non-parametric analysis of variance was used. Whenever significant differences were found the Mann-Whitney (MW) a posteriori test with Bonferroni's correction was applied (SOKAL; ROHLF, 1998). Differences in TL distribution between inner shelf (IS) trawls at depths of less than $50 \mathrm{~m}$, and outer shelf (OS) trawls at depths greater than $50 \mathrm{~m}$, were evaluated with the KS test. The DWTL relationships for the two species were calculated by linear regression analysis, and compared by the analysis of covariance (ANCOVA) test (SOKAL; ROHLF, 1998). In every case 0.05 was used as the statistical significance level. 


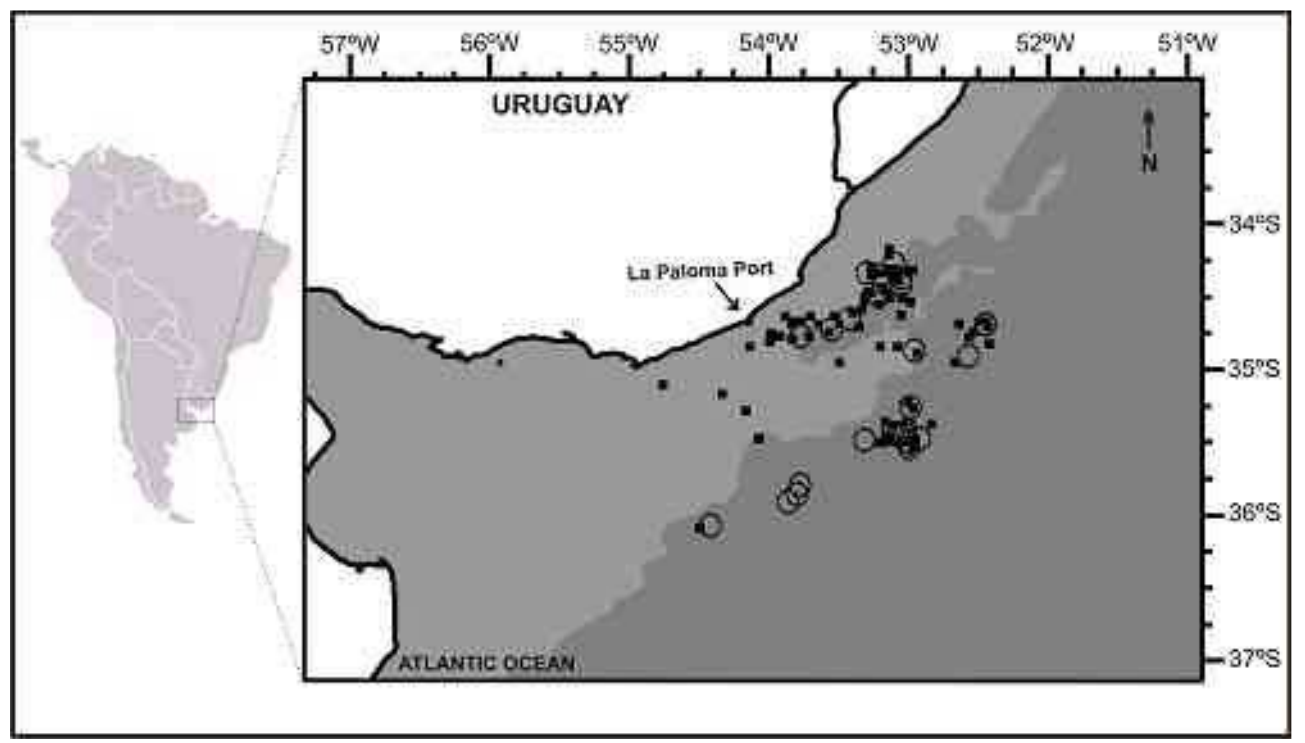

Fig. 1. Map of the Uruguayan continental shelf. Black squares indicate position of fishing hauls with occurrence of both species, empty circles show trawls only with occurrence of Atlantoraja castelnaui (there were no trawls with only Atlantoraja cyclophora). The darkest grey area is for depths $>50 \mathrm{~m}$ (Outer shelf), while the light grey area indicates areas with depth $<50 \mathrm{~m}$ (Inner shelf).

\section{REsULT}

A total of 1045 individuals of A. cyclophora (529 males and 516 females) and 772 of A. castelnaui (362 males and 410 females) were considered for the analysis. Non-significant differences in TL composition between different mesh sizes were found for A. cyclophora $(\mathrm{KW}=2.32, \mathrm{p}=0.313)$; for $A$. castelnaui the $60 \mathrm{~mm}$ net captured individuals of smaller size than the others $\left(\mathrm{KW}=15.94, \mathrm{p}=3.47 \times 10^{-4}\right)$. As the $40 \mathrm{~mm}$ and $100 \mathrm{~mm}$ nets catch showed no significant differences and the $60 \mathrm{~mm}$ net captured smaller individuals than that of $40 \mathrm{~mm}$, the differences were considered to be unrelated to mesh size and all the nets were analyzed together.

There were significant differences in TL composition between sexes, the females being larger than males for both species (A. Cyclophora: $\mathrm{KS}=0.170, \mathrm{p}=4.10 \times 10^{-7}$; A. Castelnaui: $\mathrm{KS}=0.333$, $\left.\mathrm{p}=2.83 \times 10^{-19}\right)$. Frequency analysis for $A$. cyclophora showed that males predominated up to $53 \mathrm{~cm}$ TL, whereas in A. castelnaui females predominated up to $40 \quad \mathrm{~cm} \quad \mathrm{TL} \quad$ (Figs $2, \quad 3$ ).

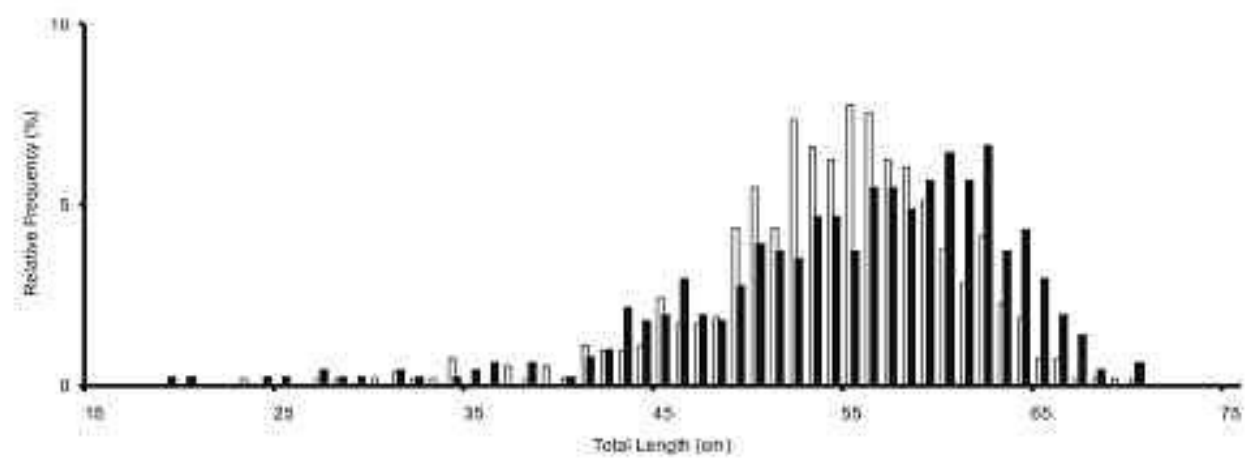

Fig. 2. Catch structure of the total data for Atlantoraja cyclophora represented by the relative frequency of total length $(\mathrm{cm})$, for males (white bars) and females (black bars). 


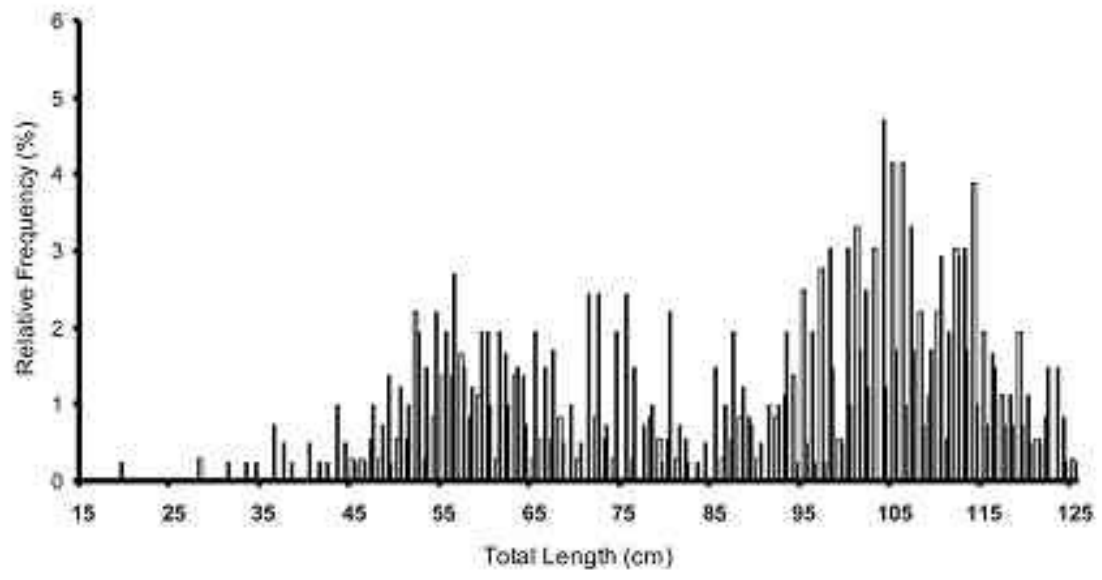

Fig. 3. Catch structure of the total data for Atlantoraja castelnaui represented by the relative frequency of total length $(\mathrm{cm})$, for males (white bars) and females (black bars).

Seasonal variations in TL data for $A$. cyclophora (Figs 4, 5) were only significant for males $\left(\mathrm{KW}=29.06, \mathrm{p}=2.26 \times 10^{-6}\right)$ between fall and spring, and also between fall and summer. Atlantoraja castelnaui showed significant differences in TL data between all seasons for males (KW=41.19, $\mathrm{p}=6.045 \times 10^{-9}$ ) except between spring and winter when smaller individuals predominated (Fig. 6) and for females $\left(\mathrm{KW}=98.03, \mathrm{p}=4.186 \times 10^{-21}\right)$ with smaller length towards spring (Fig. 7). Descriptive statistical estimators of the seasonal TL data for both species are summarized in Table 1. Significant differences in TL distribution between IS and OS were found only for females and males of $A$. castelnaui (KS=0.433, $\mathrm{p}=3.323 \times 10^{-16}$ for females and $\mathrm{KS}=0.414$, $\mathrm{p}=7.239 \times 10^{-13}$ for males) (Fig. 8).

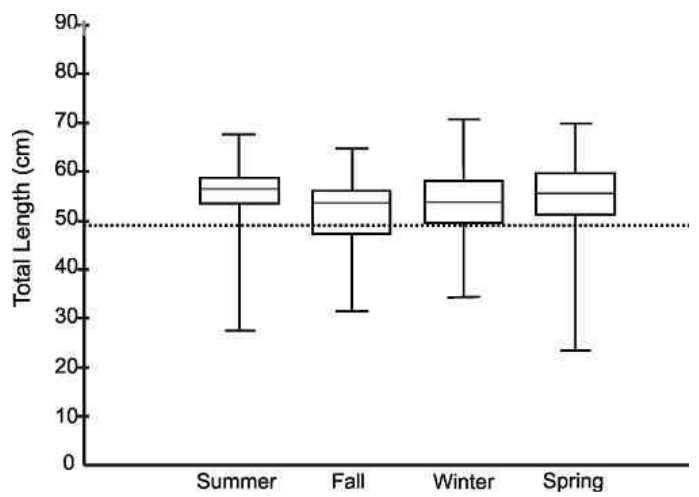

Fig. 4. Total length catch structure for males of Atlatoraja cyclophora in every season, the dotted horizontal line represents the size at sexual maturity as reported by Oddone and Vooren (2005).

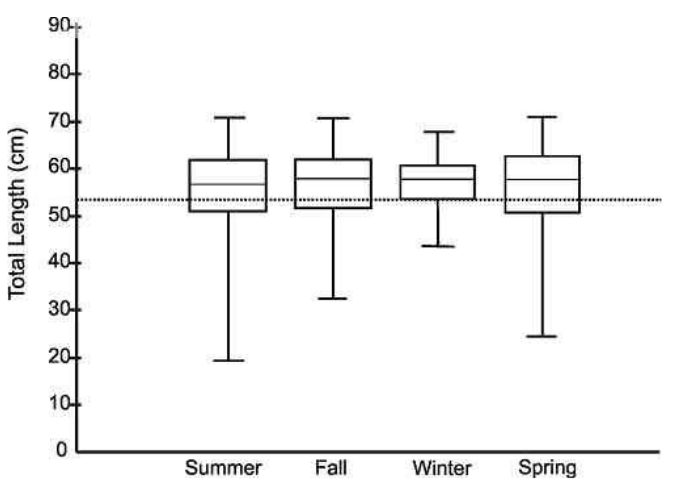

Fig. 5. Total length catch structure for females of Atlantoraja cyclophora in every season, the dotted horizontal line represents the size at sexual maturity as reported by Oddone and Vooren (2005).

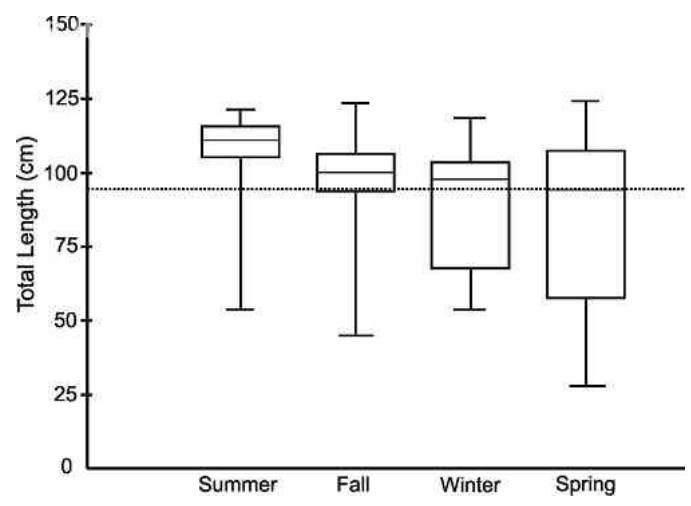

Fig. 6. Total length catch structure for males of Atlantoraja castelnaui in every season, the dotted horizontal line represents the size at sexual maturity as reported by Oddone et al. (2005). 


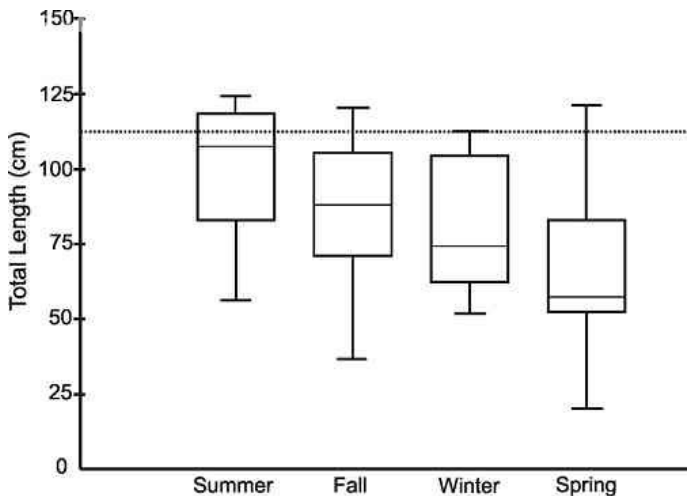

Fig. 7. Total length catch structure for females of Atlantoraja castelnaui in every season, the dotted horizontal line represents the size at sexual maturity as reported by Oddone et al. (2005)

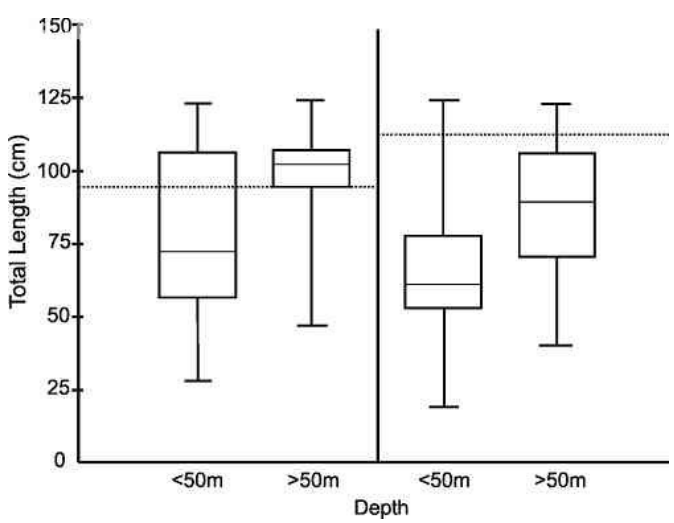

Fig. 8. Total length catch structure sorted by sex an occurrence on inner shelf (depth $<50 \mathrm{~m}$ ) or outer shelf (depth $>50 \mathrm{~m}$ ), of Atlantoraja castelnaui. The solid vertical line divides males, in the left panel, and females in the right panel, the dashed horizontal line in each panel indicates the size at first maturity for the corresponding sex as reported by Oddone et al. (2005).
Seasonal sex ratio was not significantly different from 1:1 except for A. cyclophora during summer $\left(\mathrm{p}=8.19 \times 10^{-18}\right)$ and spring $(\mathrm{p}=0.0070)$, when females and males were predominant, respectively. Proportions of mature individuals by sex and species for each season are shown in Table 1. Mature individuals of $A$. cyclophora predominated over immature ones in all seasons ( $\mathrm{p}<0.05$ for all cases). Juveniles represented less than $25 \%$ of accumulated TL. Immature females of $A$. castelnaui predominated in all seasons $(\mathrm{p}<0.05)$ but summer, when mature ones attained a peak $(43 \%)$. Mature males predominated over immature ones in all seasons $(\mathrm{p}<0.05)$ except for spring when the proportions were similar, and they also presented a peak (89\%) in summer (Table 1).

The morphometric regressions between TL and DW for both species are shown in Table 2, along with the correlation coefficient and the ANCOVA values for the comparisons. Atlantoraja cyclophora presented significant differences between the sexes, while in A. castelnaui no differences were found between the sexes.

\section{Discussion}

This study shows the distribution and population structure of two species of the genus Atlantoraja on the Uruguayan continental shelf for the first time. In both species the females were larger than the males, indicating sexual dimorphism, as has already been reported for other rajids (WALMSLEYHART et al., 1999; LICANDEO et al., 2007. The probability of survival for skates is lower for males than for females, and survival rate increases with the length of individual (STOBUTZKI et al., 2002). However, in this study it is seen that, due to their larger size, females may be more vulnerable to trawling than males.

Table 1. Descriptive statistics by sex and season for A. cyclophora and A. castelnaui, Depth range $(\mathrm{m})$, number of individuals, mean, range, standard deviation (SD) and median are shown. Mature \% shows the proportions of mature individuals in the catch. * indicates dominance of one class over the other in a $\chi^{2}$ test with $\mathrm{p}<0.05$

\begin{tabular}{llllll}
\hline A. cyclophora & & \multicolumn{1}{r}{ Summer } & \multicolumn{1}{r}{ Fall } & Winter & \multicolumn{1}{c}{ Spring } \\
\hline Depth range & & $40-100$ & $19.7-114$ & $30.9-85.6$ & $26.5-$ \\
Males & & & 116 & 56 & 70 \\
& Number & 88 & 54.5 & 53.1 & 54.7 \\
& Mean & 54.5 & 51.2 & $34-70$ & $23-69$ \\
& Range & $27-67$ & $31-64$ & 34.99 & 0.38 \\
& SD & 0.77 & 0.61 & 0.99 & 55 \\
& Median & 56 & 53 & 53 & $89^{*}$ \\
\hline
\end{tabular}


Table 1. Continuation.

\begin{tabular}{|c|c|c|c|c|c|}
\hline A. cyclophora & & Summer & Fall & Winter & Spring \\
\hline \multirow[t]{6}{*}{ Females } & Number & 135 & 124 & 47 & 210 \\
\hline & Mean & 53.9 & 55.5 & 56.3 & 55.1 \\
\hline & Range & $19-70$ & $32-70$ & $43-67$ & $24-70$ \\
\hline & SD & 0.83 & 0.64 & 0.9 & 0.54 \\
\hline & Median & 56 & 57 & 57 & 57 \\
\hline & Mature \% & $68^{*}$ & $70^{*}$ & $77 *$ & $65^{*}$ \\
\hline A. castelnaui & & Summer & Fall & Winter & Spring \\
\hline Depth range & & $53.1-80.6$ & $19.7-114$ & $30.9-100$ & $21.4-70$ \\
\hline \multirow[t]{6}{*}{ Males } & Number & 44 & 143 & 40 & 125 \\
\hline & Mean & 107.6 & 97.5 & 90.4 & 84.3 \\
\hline & Range & $54-122$ & $45-124$ & $54-119$ & $28-125$ \\
\hline & $\mathrm{SD}$ & 2.24 & 1.38 & 2.82 & 2.36 \\
\hline & Median & 112 & 101 & 98 & 95 \\
\hline & Mature \% & $89 *$ & $80^{*}$ & $66^{*}$ & 50 \\
\hline \multirow[t]{6}{*}{ Females } & Number & 56 & 150 & 63 & 141 \\
\hline & Mean & 101.2 & 87.5 & 80.3 & 67.2 \\
\hline & Range & $56-125$ & $36-121$ & $51-113$ & $19-122$ \\
\hline & SD & 2.86 & 1.62 & 2.5 & 2.02 \\
\hline & Median & 108 & 88 & 74 & 57 \\
\hline & Mature \% & 43 & $12 *$ & $8 *$ & $9 *$ \\
\hline
\end{tabular}

Table 2. Regression equation of disc width (DW) as a function of total length (TL) for males (M) and females (F) of A. cyclophora and A.castelnaui. The correlation coefficient ( $\mathrm{r}$ ), the number of individuals $(\mathrm{N})$ and the value of the statistic Fs for the comparison between sexes for this study are shown, * indicates significance.

\begin{tabular}{lccccc}
\hline & Sex & Equation & r & N & Fs \\
\hline A. cyclophora & M & DW $=-0.816+0.754(T L)$ & 0.78204 & 518 & $2.72 *$ \\
& $\mathrm{~F}$ & $\mathrm{DW}=-0.057+0.751(T L)$ & 0.8509 & 508 & \\
& & & & & \\
A. castelnaui & $\mathrm{M}$ & $\mathrm{DW}=-0.724+2.903(T L)$ & 0.98716 & 314 & 0.03 \\
& $\mathrm{~F}$ & $\mathrm{DW}=-0.738+3.131(T L)$ & 0.98092 & 379 & \\
\hline & & & & &
\end{tabular}

Neither of the sexes of A. cyclophora attained commercial weight (individuals heavier than 2 $\mathrm{kg}$, Oddone and Amorim, 2007) and therefore all individuals were probably discarded by the commercial fishing vessels. For $A$. castelnaui individuals longer than $60 \mathrm{~cm}(2 \mathrm{~kg}$ total weight, ODDONE and AMORIM, 2007) were of commercial value; at this size the percentage of captured females was greater than that of males.

In the current study A. cyclophora showed a relatively uniform size distribution of mature individuals in space. The absence of differences in size composition between the inner and outer shelf suggests a homogeneous length distribution in the study area. The fishing trawls affected mostly individuals over the size at maturity; this is an important aspect to be considered when elaborating conservation measures for this species. The low percentage of juveniles in the catch could be due to the selectivity of the fishing gear or to their mainly being distributed outside the area where the vessels operated. No major differences or trends were found in the seasonal analysis, nor were there any variations in the sex compositions or the mature/immature ratio despite the variations in seasonal length distribution for males, and this coincides with the proposal of a non-seasonal 
reproductive cycle in Brazilian waters (ODDONE; VOOREN, 2005; ODDONE; VELASCO, 2006; ODDONE et al., 2008b).

For A. castelnaui the highest percentage of mature females in the catch was found in summer, coincident with the peak in egg laying females during January reported by Peres and Vooren (1993). The seasonal tendency to smaller lengths from summer to spring could be related to the migration patterns of adults, possibly associated with reproduction. The spatial pattern detected suggests the existence of a juvenile zone in areas up to $50 \mathrm{~m}$ depth, in accordance with Oddone and Amorim (2007), for southern Brazilian waters. This has already been reported for other elasmobranchs in the same fishing area (PEREYRA et al., 2008) and coincides with the proposal of Vooren (1997) for this species in Brazilian waters. For this fishery, in all seasons, more than $50 \%$ of the females caught were below the estimated size at maturity. From 1994 to 1999 the biomass of $A$. castelnaui has decreased by $75 \%$, probably because of bottom trawl fishery (HOZBOR et al., 2004). At species level, the skate's size has been considered a major predictor for vulnerability and extinction risk (DULVY; REYNOLDS, 2002; GARCÍA et al., 2007); in all cases species with large body size are considered more vulnerable. A. castelnaui is one of the largest rajids in the area; this indicates this species' high sensibility to exploitation and the need for concern about the current lack of knowledge in the area.

The disc width/total length relationships of A. cyclophora were similar to those of other species estimated for southern and southeastern Brazil (ODDONE; VOOREN, 2004; ODDONE; AMORIM, 2007). Although differences were found, especially in the intercept, this could be due to different degrees of muscular retraction in the skates caused by fishing and manipulation (TEMPLEMAN, 1987). For A. castelnaui differences are more important, possibly because the only antecedent suitable for comparison (ODDONE; AMORIM, 2007) has a relatively small $n$ and a greater size range than in this study.

When subjected to high fishing mortality, rajids that mature later are replaced by smaller species that mature earlier (WALKER; HISLOP, 1998; DULVY et al., 2000; SWAIN et al., 2005; LICANDEO et al., 2007). Dipturus chilensis showed a reduction in its average length and observed maximum length after a short fishing period in this region and a clear decrease in size-at-maturity as a consequence of fishing (PAESCH; ODDONE, 2008). Although this coastal fishery records rajid catches, not discriminated by species since 1977 (PAESCH; DOMINGO, 2003; MASSA; HOZBOR, 2003; VILLWOCK DE MIRANDA; VOOREN, 2003), this study constitutes the first analysis of population structure by fishing trawls.

\section{ACKNOWLEDGEMENTS}

The authors wish to thank P. Troncoso, F. Castillo, J. Leguizamón (Balú), L. López, M. Gómez, F. Pintos, G. Martínez, P. Salcedo, G. Pastor and H. Alvarez, for the onboard sampling, Dra Cristina Oddone for making important comments on the preliminary version of this manuscript and the three anonymous referees whose comments greatly improved this study which is the result of an internship undertaken by L.O. and I.P. at the Uruguayan National Office of Aquatic Resources (DINARA), (Convenio UDELAR-Facultad de Ciencias-Ministerio de Ganadería, Agricultura y Pesca-DINARA).

\section{REFERENTES}

COUSSEAU, M. B.; PERROTTA, R. G. Peces marinos de Argentina: biología, distribución, pesca. Mar del Plata: INIDEP, 2004. $167 \mathrm{p}$.

DULVY, N. K.; REYNOLDS, J. D. Predicting extinction vulnerability in skates. Conserv. Biol., v. 16, n. 2, p. 440-450, 2002

DULVY, N. K.; METCALFE, J. D.; GLANVILLE, J.; PAWSON, M. G.; REYNOLDS, J. D. Fishery stability, local extinctions, and shifts in community structure in skates. Conserv. Biol., v. 14, n. 1, p. 283-293, 2000.

EBERT, D. A.; SULIKOWSKI, J. A. Biology of skates. Netherlands: Springer, 2007. 243 p.

GARCÍA, V.; LUCIFORA, L.; MYERS, A. The importance of habitat and life-history to extinction risk in sharks, skates, rays and chimaeras. Proc. R. Soc., Lond., B, v. 275, n. 1, p. 83-89, 2007.

HOLDEN, M. J. Are long-term sustainable fisheries for elasmobranch possible? Rapp. P.-V. Reun. CIESM, v. 164, p. 360-367, 1973.

HOZBOR, N.; MASSA, A.; VOOREN, C. M. IUCN Red list of threatened species, Version 2009.1. <www.iucnredlist.org>. Downloaded on 20 April 2010, 2004.

LICANDEO, R.; CERNA, F.; CESPEDES, R. Age, growth, and reproduction of the roughskin skate, Dipturus trachyderma, from the southeastern Pacific. ICES J. mar. Sci., v. 64, n. 1, p.141-148, 2007.

MCEACHRAN, J. D.; DE CARVALHO M. R. Batoid fishes. In: FAO species identification guide for fishery purposes. The living marine resources of the Western Central Atlantic. v. 1: Introduction, molluscs, crustaceans, hagfishes, sharks, batoid fishes, and chimaeras. Rome: FAO, 2002. p. 507-530.

MASSA, A. M.; HOZBOR, N. M. Peces cartilaginosos de la plataforma argentina: Explotación, situación y necesidades para un manejo pesquero adecuado. Frente Marit., v. 19, n. 1, p. 199-206, 2003.

MENNI, R.C. Rajidae del litoral bonaerense. I. Espécies de los géneros Raja, Bathyraja y Sympterygia (Chondrichtyes). Physis, Seccion a., v. 32, p. 413-439, 1973. 
ODDONE, M. C.; AMORIM, A. F. Lengthweight relationships, condition and population structure of the genus Atlantoraja (Elasmobranchii,Rajidae, rhynchobatidae) in South-eastern Brazilian waters, SW Atlantic Ocean. J. Northwest Atl. Fish. Soc., v. 38, p. 43-52, 2007.

ODDONE, M. C.; VELASCO, G. Relationship between liver weight, body size and reproductive activity in Atlantoraja cyclophora (Elasmobranchii: Rajidae: Arhynchobatinae) in oceanic waters off Rio Grande do Sul, Brazil. Neotrop. Biol. Conserv., v. 1, n. 1, p. 12 $16,2006$.

ODDONE, M. C.; VOOREN, C. M. Distribution and abundance of Atlantoraja cyclophora (Regan 1903) (Elasmobranchii, Rajidae) with regard to salinity, temperature and depth in southern Brazil, south-western Atlantic. Neotrop. Ichthyol., v. 2, n. 3, p. 137-144, 2004.

ODDONE, M. C.; VOOREN, C. M. Reproductive biology of Atlantoraja cyclophora (Regan 1903) (Elasmobranchii: Rajidae) off southern Brazil. ICES J. Mar. Sci., v. 62, p. 1095-1103, 2005.

ODDONE, M. C.; PAESCH, L.; NORBIS, W. Length at first sexual maturity of two species of rajoid skates, genera Atlantoraja and Dipturus (Pisces, Elasmobranchii, Rajidae), from the southwestern Atlantic Ocean. J. appl. Ichthyol., v. 21, p. 70-72, 2005.

ODDONE, M. C; AMORIM, A. F.; MANCINI, P. L. Reproductive biology of the spotback skate, Atlantoraja castelnaui (Ribeiro, 1907) (Chondrichthyes, Rajidae) in southeastern Brazilian waters. Rev. Biol. Mar., v. 43, n. 2, p. 327-334, 2008a.

ODDONE, M. C.; NORBIS, W.; MANCINI, P. L.; AMORIM, A.F. Sexual development and reproductive cycle of the Eyespot skate Atlantoraja cyclophora (Regan, 1903) (Chondrichthyes: Rajidae: Arhynchobatinae), in southeastern Brazil. Acta Adriat., v. 49, n. 1, p. 73-87, 2008b.

PAESCH, L.; DOMINGO, A. La pesca de condrictios en el Uruguay. Frente Marit. v. 19, n. 1, p. 207-216, 2003.

PAESCH, L.; ODDONE, M. C. Size at maturity and egg capsules of the softnose skates Bathyraja brachyurops (Fowler, 1910) and Bathyraja macloviana (Norman, 1937) (Elasmobranchii: Rajidae) in the SW Atlantic (37 $00^{\circ}-39^{\circ} 30^{\prime}$ 'S). J. appl. Ichthyol., v. 25, p. 66-71, 2008.

PERES, J. A; VOOREN, C. M. Ciclo reproductivo de quatro espécies do gênero Raja do Sul do Brasil. REUNIÃO GRUPO DE TRABALHO PESCA E PESQUISA TUBARÕES E ARRAIAS NO BRASIL, 6., Recife, Pernambuco, 1993. Resumo, 1993.

PEREYRA, I.; ORLANDO L.; NORBIS W.; PAESCH L. Variación espacial y temporal de la composición por tallas y sexos del gatuso Mustelus schmitti Springer, 1939 capturado por la pesca de arrastre en la costa oceánica uruguaya durante 2004. Rev. Biol. mar., v. 43, n. 1, p. 159-166, 2008.
SWAIN, D. P.; HURLBUT T.; BENOÎT, H. P. Changes in the abundance and size of skates in the southern Gulf of St. Lawrence, 1971-2002. J. Northwest. Atl. Fish. Soc., v. 36, n. 1, p. 19-30, 2005.

SOKAL, R. R.; ROHLF, F. J. Biometry: the principles and practice of statistics in biological research. New York: W.H. Freeman and Company, 1998. 850 p.

STEVENS, J. D.; BONFIL R.; DULVY, N. K.; WALKER, P. A. The effects of fishing on sharks, rays, and chimaeras (chondrichthyans), and the implications for marine ecosystems. ICES J. mar. Sci., v. 57, p. 476494, 2000.

STOBUTZKI, I. C.; MILLER, M. J.; HEALES, D. S.; BREWER, D.T. Sustainability of elasmobranchs caught as bycatch in a tropical prawn (shrimp) trawl fishery. Fish. Bull. U.S. v. 100, p. 800-821, 2002.

TEMPLEMAN, W. Differences in sexual maturity and related characteristics between populations of thorny skate (Raja radiata) in the northwest Atlantic. J. Northwest. Atl. Fish. Sci., n. 7, p. 155-167, 1987.

VILLWOCK DE MIRANDA, V.; VOOREN, C. M. Captura e eforço da pesca de elasmobranquios demersais no sul do Brasil. Nos anos de 1975 a 1995. Frente Marit., v. 19, n. 1, p. 217-231, 2003.

VOOREN C. M. Demersal elasmobranchs. In: U. SEELIGER, U.; ODEBRECHT, C. ; CASTELLO J.P.(Ed.). Subtropical Convergence Environments: The coast and sea in the Southwestern Atlantic. Berlin: Springer-Verlag, 1997. p. 141-146.

VOOREN, C. M.; KLIPPEL, S. Biologia e status de conservação do cação-listrado Mustelus fasciatus: In: VOOREN, C. M.; KLIPPEL S. (Ed.). Ações para a conservação de tubarões e raias no sul do Brasil. Porto Alegre: Igaré, 2005. p. 83-96.

WALKER, P. A.; HISLOP, J. R. G. Sensitive skates or resilient rays? Spatial and temporal shifts in ray species composition in the central and north-western North Sea between 1930 and the present day. ICES J. mar. Sci, v. 55, p. 392-402, 1998.

WALMSLEY-HART, S. A.; SAUER, W.; BUXTON, C. D. The biology of the skates Raja wallacei and $R$. pullopunctata (Batoidea: Rajidae) on the Agulhas Bank, South Africa. S. Afr. J. mar. Sci, v. 21, n. 1, p. 165179, 1999.

ZAR, J.H. Biostatistical analysis. Upper Saddle River, NJ: Prentice Hall, 2004. 663 p.

(Manuscript received 02 January 2011; revised 16 March 2011; accepted 05 July 2011) 